\title{
INTERNATIONAL APPLICATION MODEL SHORT-LONG TERM BETWEEN GDP AND CONSUMPTION : CASE STUDY INDONESIA
}

\author{
Teguh Sugiarto, \\ Dept. Accounting Universitas Budi Luhur, Jl. Ciledug Raya, Petukangan Utara, Pesanggrahan, Jak- \\ Sel, DKI Jakarta, Indonesia \\ Ludiro Madu \\ Lecture at UPN Veteran Departemen Internasional Relation. Universitas Pembangunan \\ 'Nasional' Veteran, Yogyakarta, Indonesia \\ Ahmad Subagyo \\ Lecture at STIE GICI Business Scholl, Depok, Jawa Barat, Indonesia \\ Sugiyanto \\ Lecture at Dept. Acc. Universitas Pamulang Tangerang, Banten, Indonesia \\ Achmadi \\ Lecture at STIE Tunas Nusantara, Kota Jakarta Selatan, Daerah Khusus Ibukota Jakarta 12430, \\ Indonesia
}

date of paper receipt:

03.01.2018.

Orginal article date of sending to review:

08.01.2018. date of review receipt:

25.01.2018.

\section{SUMMARY}

More recently, significant fluctuations in the Indonesian economy justify the need to pay more attention to this issue. In this case, the main purpose of this research is to know the relationship between two issues related to Indonesian macro economy called consumption and GDP for data period during 1967 until 2014. This study investigates the relationship between GDP variables and Indonesian consumption consumption variables using the test ARDL, cointegration and Granger causality. The result of the research can be concluded that, there is long-run equilibrium relationship between GDP and consumption with long-term ARDL model, 10\% change of consumption will produce long-term change of $44 \%$ in GDP. It is not surprising that there is no short-run equilibrium relationship between GDP and consumption. 10\% of consumption will result in a short-term ARDL model change of 95\% in GDP. The variables and consumption of GDP are cointegrated in the long run significantly at lag interval 10, whereas the use of lag interval 1 and 5 is not credited in the long run. Using a cointegration test with lag interval 1, 5 and 10 indicates significant for all usage slowness. So it can be summarized in the context of GDP and coordinated short-term economic consumption for all the prevailing interval lags. concluded that long-term causality test results between GDP variables and significant consumption with time intervals 5 and 10. intervals 1, 15 and 20 have no long-term causality relationship between GDP variables and consumption variables. a short-term causal model. With lagging intervals of 1, 5, 10 and 15, there is a short-term causal relationship between the variable GDP and consumption. As for the use of delay interval 20 there is no causal relationship in the short term between the variable GDP and consumption in Indonesia.

Keywords: $A R D L$, cointegration, granger causality, GDP, consumption. 


\section{INTRODUCTION}

During these years, a lot of researches have been conducted which focuse on the policies used by the Government, in both fiscal and monetary issues. Nevertheless, A small portion of the them are related to the issue of fiscal policy which mainly has the purpose of or in connection with the issue of the national economy in particular. economic problems in the country such as the onset of price hikes, shortages of the State budget and declining tax revenue have resulted in an increasing trend of government and the private sector debts. This issue has convinced the researchers to analysis it in more details. the majority of these studied aim to investigate how was the relationship between GDP and rate of consumption during 1967 to 2014 in the country. Accordingly, in a study, this relationship has been evaluated using the available database. according to following figure, it can be included that consumption had withnessed a growing trend by increace in GDP criteria.

Figure 1 GDP and consumption in Indonesia for the year 1967-2014

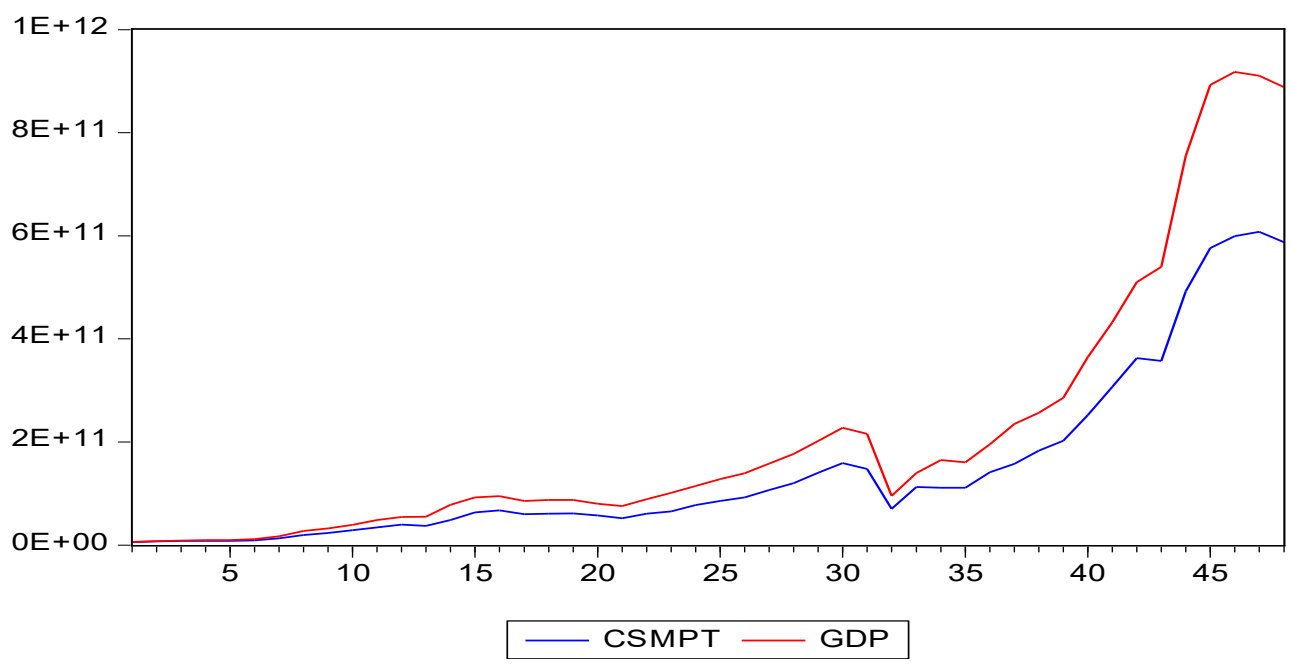

Source : Self Proceed

If the pore over the occurrence of consumption figures rise each year also on accompanied with the increase of the GDP every year too. Thus the author assumes that the two variables have a relationship that was going on explained in the study results. By using these two macroeconomic variables, expressed in actual value, expect to be able to see how the second relationship and result in this variable in the short-term and long-term, as well as on the expected can see if there is a dependency between macroeconomic variables in doing this research. This research will be divided into 5 sections, where section 1 is for introduction, part 2 for literature review, part 3 for research methods, part 4 for results research and part 5 for conclusion research that has been funded.

\section{LITERATURE REVIEW}

For literature pertaining to this study, the authors use as the basis of the literature as a basis for understanding the use of modeling in research methods that will be in use. One of them performed by Benazic, M. (2006) [1], Gray, C., et, al. (2007) [2], Rukelj, D. (2009) [3] Svaljek, S. et. Al (2009) [4]. The two researchers do a study related to GDP that exists in their country and relating to the fiscal policy in the activities of the economy. Most of the variables used by them in addition to GDP is an expenditure budget and expenses. The analysis model in use among others such as Granger method, model and vector error correction model of error correction. From the results of their research that, variables in use will have elevated to government revenue as well as have a negative impact on the real sector activity in their country, while government spending figures had 
a positive impact on the real sector economy. Other analysis in use by the author namely HodrickPrescott filter technique. The author identifies that a cycle happens one considered very sensitive on variable budget revenues and spending as well as against the macroeconomic variables are variables in the thorough.

Gross Domestic Product (GDP) / Gross Domestic Product (GDP) Definition, Types and approach Gross Domestic Product (GDP) is a calculation used by a country as the main measure for the activity of national economy, but basically the whole GDP measures the volume of production of a region (country) geographically. Meanwhile, according to Samuelson. \& Nordhaus (2001) [5], Slavin (1999) [7] and Begg, et al (2001) [8] defines GDP as a means to measure the market value of the goods and services produced by the end of the resources that are within a country during a certain period, usually one year. GDP can also be used to study the economy over time or to compare several economies at a time.

According to Samuelson. \& Nordhaus $\neg$ (2001) [5], McEachern (2000: 147) [6], Slavin (1999) [7] and Begg, et al (2001) [8] There are two kinds of approaches used in the calculation of GDP, namely: 1. the expenditure approach, aggregating all aggregate spending on all final goods and services produced during a year. 2 . The income approach, aggregating all the aggregate income received during the year by those who produce the output.

\section{GDP BY EXPENDITURE APPROACH}

According to Samuelson. \& Nordhaus (2001) [5], McEachern (2000: 149) [6], Slavin (1999) [7] and Begg, et al (2001) [8] to understand the expenditure approach to GDP, we split expenses aggregated into four components, consumption, investment, government purchases, and net exports. We will discuss them one by one

1. Consumption, or more specifically private consumption expenditure, is the purchase of final goods and services by households for one year.

2. Investment, or, more specifically, gross private domestic investment, is spending on new capital goods and additional inventory.

3. Purchase of government, or more specifically government consumption and gross investment, including all levels of government spending on all goods and services, from street cleaning to purge the courtroom, from library books to pay the librarian. In the government's purchase does not include social security, welfare and unemployment insurance. Because these payments reflects the government grants to the recipient and do not reflect the impact of the government.

4. Net exports, equal to the value of exports of goods and services a country minus imports of goods and services the country. Net exports not only includes the value of trade in goods but also services. In Samuelson. \& Nordhaus (2001) [5], Slavin (1999) [7] and Begg, et al (2001) [8] approach to spending, aggregate state spending equal to the sum of consumption, $C$, investment $I$, government purchases, G, and net exports, the value of exports, $X$, deducting the value of imports, $M$, or (XM) the sum of these components generate aggregate spending, or GDP:

$\mathrm{C}+\mathrm{I}+\mathrm{G}+(\mathrm{X}-\mathrm{M})=$ Expenses aggregate $=\mathrm{GDP}$

\section{GDP BY INCOME APPROACH}

According to Samuelson. \& Nordhaus (2001) [5], McEachern (2000: 151) [6], Slavin (1999) [7] and Begg, et al (2001) [8] The aggregate income is equal to the sum of all earned income of the owner resources in the economy (because of the resources used in the production process). Double-entry bookkeeping system can ensure that the value of aggregate output equals aggregate income paid to the resources used in the production of such outputs: ie wages, interest, rents, and profits of production. 
According to Mankiw (2005) [9], and McEachern (2000: 151) [6]. Aggregate expenditure = GDP is a finished product normally processed by several companies on his way to the consumer. Wooden table, for example, initially as raw wood, then cut by the first company, cut to fit the needs of furniture by a second company, created a table by a third company, and sold by the four companies. Double counting avoided by simply taking into account the market value of the counter at the time of sale to the end user or by calculating the value added at each stage of production. The added value of each company is the same with the selling price of the company is reduced by the amount paid on inputs other companies.

The added value of each phase reflects the return on the owner of the resource at the stage in question. Summation added value at all stages of production equal to the market value of final goods, and the sum of the entire value-added final goods and services is equal to the GDP by the income approach [19].

\section{DATA AND RESEARCH TECHNIQUE ANALISYS}

Author uses the data in this study is GDP and consumption Indonesia country, from the year 19672014.

\section{ARDL ANALYSIS}

In the method of this study the author makes the equation based on existing empirical literature, where the existence of a long-term relationship between GDP and consumption. where the gross domestic product and consumption in GDP and symbolizes with ELC. Data on the use of annual data is uploaded by the author through the website of the world bank on June 13, 2016. The first step the author will use test ARDL in the short and long term to know the relationship of the economic variable.

\section{COINTEGRATION ANALYSIS}

This cointegration method to the author proposes a model developed by Pesaran \& Shin (1999) [10]. Using the approach of cointegration Johansen (1988) [11], or using the Johansen and Juselius (1990) [12] consider easier in understand and funded although ARDL method has many advantages compared to other such as cointegration methods Granger (1969) [13], Engle \& Granger (1987) [14]. In research in writers ignores while Johansen cointegration techniques with large data samples, which could expect to make the validation process be accurate. If we see the ARDL method by using a simple equation, log-linear function in the long term will expect to have a relationship between variables in thoroughly.

However, in the data analysis, the writer is intentionally looking to the model of Narayan (2005), Narayan \& Smith (2008), Narayan \& Prasad (2008) [15], [16], [17] and are bound to the model Pesaran et al. (2001) [18], where a variable period of time in a thorough range of 30 or over. If there is a long-term relationship between variables in the model

\section{CAUSALITY ANALYSIS}

in their study, the relationship between Engle and Granger has been studied (1987) [14], The author did not do the test over Granger causality based error correction model. Same is the case with the test, test the Granger causality also in this study with model the long term and short term. 


\section{RESULT AND DISCUSSION}

Analysis of the results of this research will be in the form of outlines in table 1 to table 6 :

\section{ARDL MODEL LONG RUN GDP AND CONSUMPTION}

ARDL model test of use for long term analysis, at the got results of the relationship between GDP and consumption variables for a meticulous data as follows:

Table 1 ARDL Model Long run GDP and consumption in Indonesia for the year 1967-2014

\begin{tabular}{|l|c|c|c|c|}
\hline Dependent Variable: GDP(-1) & & \\
\hline Variable & Coefficient & Std. Error & t-Statistic & Prob. \\
\hline GDP(-2) & 0.445209 & 0.112365 & 3.962166 & 0.0003 \\
\hline CSMPT(-1) & 1.508347 & 0.038512 & 39.16600 & 0.0000 \\
\hline CSMPT(-2) & -0.649933 & 0.177236 & -3.667052 & 0.0007 \\
\hline C & 5.390008 & 2.510009 & 0.215011 & 0.8309 \\
\hline$@ T R E N D$ & -2.660008 & 1.570008 & -1.696484 & 0.0976 \\
\hline R-squared & 0.998766 & \multicolumn{2}{|c|}{ Mean dependent var } & 2.090011 \\
\hline Adjusted R-squared & 0.998643 & \multicolumn{2}{|c|}{ S.D. dependent var } & 2.430011 \\
\hline S.E. of regression & 8.960009 & \multicolumn{2}{|c|}{ Sum squared resid } & 3.210021 \\
\hline Durbin-Watson stat & 1.787825 & \multicolumn{2}{|c|}{ Long-run variance } & 4.450019 \\
\hline
\end{tabular}

Source : Self Proceed

The long run value of coefficient is positive (4.450019), as required, and is not significant. Importantly, the long-run coefficients from the ARDL equation are reported, with their standard errors, t-statistics, and p-values. First, not surprisingly, there's a long-run equilibrium relationship between the GDP and the consumption with ARDL long run model. Second, there is a relatively quick adjustment in the GDP when the consumption changes. Third, a 10\% change in the consumptions will result in a long-run change of $44 \%$ in the GDP.

\section{ARDL MODEL SHORT RUN GDP AND CONSUMPTION}

Here, ARDL test has been used for the the short-term Analysis and the results is shown in the following table.

Table 2 ARDL Model short run GDP and consumption in indonesia for the year 1967-2014

\begin{tabular}{|c|c|c|c|c|}
\hline \multicolumn{3}{|c|}{ Dependent Variable:_GDP(-1) } & \multirow[b]{2}{*}{ t-Statistic } & \multirow[b]{2}{*}{ Prob. } \\
\hline Variable & Coefficient & Std. Error & & \\
\hline GDP(-2) & -0.063131 & 0.098076 & -0.643691 & 0.5234 \\
\hline CSSMPT $(-1)$ & 1.480463 & 0.035796 & 41.35793 & 0.0000 \\
\hline CSMPT(-2) & 0.226323 & 0.146239 & 1.547627 & 0.1296 \\
\hline $\mathrm{C}$ & 9.150008 & 1.950009 & 0.469012 & 0.6416 \\
\hline @TREND & -80789154 & 80840215 & -0.999368 & 0.3236 \\
\hline R-squared & 0.956290 & \multicolumn{2}{|c|}{ Mean dependent var } & 2.010010 \\
\hline Adjusted R-squared & 0.951919 & \multicolumn{2}{|c|}{ S.D. dependent var } & 4.550010 \\
\hline S.E. of regression & 9.980009 & \multicolumn{2}{|c|}{ Sum squared resid } & 3.980021 \\
\hline Durbin-Watson stat & 1.717751 & \multicolumn{2}{|c|}{ Long-run variance } & 3.320019 \\
\hline
\end{tabular}

Source : Self Proceed 
Not the same as the long term coefficient value analysis, in the short-term analysis model using ARDL model is positive (3.320019), as needed, and not significant. Note, short-term coefficients of the ARDL equation are reported, with standard errors, $t$-statistics, and $p$ values. First, it is not surprising, if there is no short-run equilibrium relationship between GDP and consumption. Secondly, there is a relatively quick adjustment of the GDP when the consumption changes. (Remember that the data is observed every year.). Third, a change in consumption of $10 \%$ will result in a long-term change of $95 \%$ in GDP.

\section{COINTEGRATION MODEL LONG RUN GDP AND CONSUMPTION}

In a second analysis with cointegration test, the same as the previous analysis. With cointegration is the analysis of long term and short term in accordance with the equation in to draw by the author on table 3 and 4 .

Table 3 Cointegration Model Long run GDP and consumption in Indonesia for the year 1967-2014

\begin{tabular}{|c|c|c|c|c|}
\hline \multicolumn{5}{|c|}{ Lags interval (in first differences): 1 to 1} \\
\hline & & Trace & 0.05 & \\
\hline No. of $\mathrm{CE}(\mathrm{s})$ & Eigenvalue & Statistic & Critical Value & Prob. ${ }^{* *}$ \\
\hline None $^{*}$ & 0.310246 & 19.71586 & 15.49471 & 0.0109 \\
\hline At most 1 & 0.055581 & 2.630505 & 3.841466 & 0.1048 \\
\hline \multicolumn{5}{|c|}{ Lags interval (in first differences): 1 to 5} \\
\hline & & Trace & 0.05 & \\
\hline No. of CE(s) & Eigenvalue & Statistic & Critical Value & Prob. ${ }^{* *}$ \\
\hline None & 0.295077 & 14.92359 & 15.49471 & 0.0608 \\
\hline At most 1 & 0.005640 & 0.237554 & 3.841466 & 0.6260 \\
\hline \multicolumn{5}{|c|}{ Lags interval (in first differences): 1 to 10} \\
\hline & & Trace & 0.05 & \\
\hline No. of CE(s) & Eigenvalue & Statistic & Critical Value & Prob. ${ }^{* *}$ \\
\hline None* & 0.478634 & 31.79177 & 15.49471 & 0.0001 \\
\hline At most $1^{\star}$ & 0.187739 & 7.693531 & 3.841466 & 0.0055 \\
\hline
\end{tabular}

Table 3 shows long-term cointegration test results for GDP variables and consumption with cointegration using lags of intervals 1, 5 and 10. The results in the table above show GDP and consumption variables cointegrated in the long term significantly at lags interval 10, whereas the use of interval lags 1 and 5 are not mutually credited in the long run. 


\section{COINTEGRATION MODEL SHORT RUN GDP AND CONSUMPTION}

Display the following results for the analysis of the short-term test with cointegration.

Table 4 Cointegration Model short run GDP and consumption in Indonesia for the year 1967-2014

\begin{tabular}{|c|c|c|c|c|}
\hline \multicolumn{4}{|c|}{ Lags interval (in first differences): 1 to 1} & \\
\hline & & Trace & 0.05 & \\
\hline No. of $\mathrm{CE}(\mathrm{s})$ & Eigenvalue & Statistic & $\begin{array}{c}\text { Critical } \\
\text { Value }\end{array}$ & Prob. ${ }^{* *}$ \\
\hline None* & 0.665932 & 65.23861 & 15.49471 & 0.0000 \\
\hline At most $1^{\star}$ & 0.275171 & 14.80373 & 3.841466 & 0.0001 \\
\hline \multicolumn{4}{|c|}{ Lags interval (in first differences): 1 to 5} & \\
\hline & & Trace & 0.05 & \\
\hline No. of $\mathrm{CE}(\mathrm{s})$ & Eigenvalue & Statistic & $\begin{array}{c}\text { Critical } \\
\text { Value }\end{array}$ & Prob. ${ }^{* *}$ \\
\hline None ${ }^{*}$ & 0.370146 & 25.28477 & 15.49471 & 0.0012 \\
\hline At most $1^{*}$ & 0.130425 & 5.869537 & 3.841466 & 0.0154 \\
\hline \multicolumn{4}{|c|}{ Lags interval (in first differences): 1 to 10} & \\
\hline & & Trace & 0.05 & \\
\hline No. of $\mathrm{CE}(\mathrm{s})$ & Eigenvalue & Statistic & $\begin{array}{l}\text { Critical } \\
\text { Value }\end{array}$ & Prob. $^{* *}$ \\
\hline None ${ }^{*}$ & 0.258275 & 17.39057 & 15.49471 & 0.0256 \\
\hline At most $1^{*}$ & 0.157380 & 6.335837 & 3.841466 & 0.0118 \\
\hline
\end{tabular}

Source : Self Proceed

Table 4 above describes for short-term cointegration test results on GDP and consumption variables. Using cointegration tests with lags 1,5 and 10 interval shows significant for all usage slowness. So it can be summarized in the context of GDP and economic consumption in the short term cointegrate for all interval lags that apply.

\section{CAUSALITY MODEL LONG RUN GDP AND CONSUMPTION}

The following test results of causality for GDP and consumption variables on long-term and short term.

Table 5 Causality model long run GDP and consumption in Indonesia for the year 1967-2014

\begin{tabular}{|c|c|c|c|}
\hline \multicolumn{2}{|l|}{ Pairwise Granger Causality Tests } & & \\
\hline Null Hypothesis: & Obs & F-Statistic & Prob. \\
\hline GDP does not Granger Cause CSMPT & 47 & 0.02413 & 0.8773 \\
\hline CSMPT does not Granger Cause GDP & 0.50830 & 0.4796 \\
\hline Lags: 5 & & \\
\hline Null Hypothesis: & Obs & F-Statistic & Prob. \\
\hline GDP does not Granger Cause CSMPT & 43 & 6.37635 & 0.0003 \\
\hline CSMPT does not Granger Cause GDP & 6.77051 & 0.0002 \\
\hline Lags: 10 & & \\
\hline Null Hypothesis: & Obs & F-Statistic & Prob. \\
\hline GDP does not Granger Cause CSMPT & 38 & 3.95192 & 0.0063 \\
\hline CSMPT does not Granger Cause GDP & 3.29590 & 0.0149 \\
\hline Lags: 15 & & \\
\hline Null Hypothesis: & Obs & F-Statistic & Prob. \\
\hline
\end{tabular}




\begin{tabular}{|c|c|c|c|}
\hline GDP does not Granger Cause CSMPT & 33 & 2.19929 & 0.3569 \\
\hline \multicolumn{2}{|c|}{ CSMPT does not Granger Cause GDP } & 2.52045 & 0.3206 \\
\hline Lags: 20 & & \\
\hline Null Hypothesis: & Obs & F-Statistic & Prob. \\
\hline GDP does not Granger Cause CSMPT & 28 & NA & NA \\
\hline CSMPT does not Granger Cause GDP & NA & NA \\
\hline
\end{tabular}

Source : Self Proceed

From Table 5 above it can be concluded that long-term causality test results between GDP variables and significant consumption with time interval 5 and 10. When using lag interval 1, 15 and 20 there is no long-term causality relationship between GDP variables and consumption .

\section{CAUSALITY MODEL SHORT RUN GDP AND CONSUMPTION}

How about a short-term relationship of causality.

Table 6 Causality model short run GDP and consumption in Indonesia for the year 1967-2014

\begin{tabular}{|c|c|c|c|}
\hline \multicolumn{4}{|l|}{ Pairwise Granger Causality Tests } \\
\hline \multicolumn{2}{|l|}{ Lags: 1} & \multirow[b]{2}{*}{ F-Statistic } & \multirow[b]{2}{*}{ Prob. } \\
\hline Null Hypothesis: & Obs & & \\
\hline _GDP does not Granger Cause_CSMPT & 47 & 10.4233 & 0.0024 \\
\hline \multicolumn{2}{|c|}{ _CSMPT does not Granger Cause_GDP } & 5.15595 & 0.0281 \\
\hline \multicolumn{2}{|l|}{ Lags: 5} & & \\
\hline Null Hypothesis: & Obs & F-Statistic & Prob. \\
\hline _GDP does not Granger Cause_CSMPT & 43 & 4.08852 & 0.0055 \\
\hline \multicolumn{2}{|l|}{ _CSMPT does not Granger Cause_GDP } & 4.09612 & 0.0055 \\
\hline \multicolumn{2}{|l|}{ Lags: 10} & & \\
\hline Null Hypothesis: & Obs & F-Statistic & Prob. \\
\hline _GDP does not Granger Cause_CSMPT & 38 & 2.35351 & 0.0579 \\
\hline \multicolumn{2}{|l|}{ _CSMPT does not Granger Cause_GDP } & 2.24223 & 0.0686 \\
\hline \multicolumn{2}{|l|}{ Lags: 15} & & \\
\hline Null Hypothesis: & Obs & F-Statistic & Prob. \\
\hline _GDP does not Granger Cause_CSMPT & 33 & 2.17610 & 0.3598 \\
\hline \multicolumn{2}{|l|}{ _CSMPT does not Granger Cause_GDP } & 2.20757 & 0.3559 \\
\hline \multicolumn{2}{|l|}{ Lags: 20} & & \\
\hline Null Hypothesis: & Obs & F-Statistic & Prob. \\
\hline _GDP does not Granger Cause_CSMPT & 28 & NA & NA \\
\hline \multicolumn{2}{|l|}{ _CSMPT does not Granger Cause_GDP } & NA & NA \\
\hline
\end{tabular}

Source : Self Proceed

In table 6 above presented the test results for the causality of the model with the short term. Using lags 1, 5, 10 and 15 intervals, there is a short-term causal relationship between the variable GDP and consumption. As for the use of delay interval 20 there is no causal relationship in the short term between the variable GDP and consumption in Indonesia. 


\section{CONCLUSION}

This study identifies the relationship between GDP and annual consumption economics variables from 1967 to 2014 using ARDL, Cointegration and Causality granger analysis. not surprisingly, there is a long-run equilibrium relationship between GDP and consumption with a long-term ARDL model, a $10 \%$ change in consumption will result in long-term change of $44 \%$ in GDP. It is not surprising that there is no short-run equilibrium relationship between GDP and consumption. $10 \%$ of consumption will result in a short-term change of ARDL model of $95 \%$ in GDP. GDP variables and consumption are cointegrated in the long run significantly at lag interval 10, whereas the use of lags 1 and 5 intervals is not credited in the long run. Using a cointegration test with lag interval 1, 5 and 10 indicates significant for all usage slowness. So it can be summarized in the context of GDP and short term economic consumption that is cointegrated for all the prevailing interval lags. concludes that long-term causality test results between GDP variables and significant consumption with time intervals 5 and 10. intervals 1,15 and 20 have no long-term causality relationship between GDP and consumption variables. causal model with short term. With lagging intervals of 1,5,10 and 15, there is a short-term causal relationship between the variable GDP and consumption. As for the use of delay interval 20 there is no causal relationship in the short term between the variable GDP and consumption in Indonesia. 


\section{REFERENCES}

Benazic, M. (2006), "Fiscal Policy \& Economic Activity in Croatia with A Cointegration Analysis", Ekonomski pregled, 57(12), pp. 882-917.

Gray, et, al. (2007), Fiscal policy \& economic growth - Lessons for Eastern Europe \& Central Asia, The WB.

Rukelj, D. (2009), Modelling Fiscal \& Monetary Policy Interactions in Croatia Using SVEC Model, Privredna kretanja i ekonomska politika 121, pp. 27-58.

Svaljek et, al. (2009), Ciklicki prilagodjeni proracunski saldo: primjer Hrvatske. Privredna kretanja $i$ ekonomska politika 120, pp. 49-81.

Samuelson. Paul A. \& William D. Nordhaus, Microeconomics (2001), New York The McGraw-Hill Company, Inc.

McEachern, William A (2000) Ekonomi Makro Pendekatan Kontemporer. Edisi Indonesia, Salemba Empat, Jakarta.

Slavin, Stephen L. (1999), Macroeconomics 5th edition. New York, The McGraw-Hill Company.

Begg, David, Stanley Fischer, \& Dornbusch, R (2001) Principles of Macroenonomics 2nd Edition, USA: Harcourt College Publishers.

Mankiw, Gregory. N. (2005). Makroekonomi, Edisi Kelima : Erlangga. Jakarta.

Pesaran \& Shin (1999), "ARDL modelling approach to cointegration analysis", in: S.Storm (Ed.) Econometrics and Economic Theory in the 20th Century: The Ragnar Frisch

Johansen, S., (1988), "Statistical analysis of vector cointegration", Journal of Economic Dynamics \& Control, 12, 231-254.

Johansen \& Juselius (1990), "Maximum likelihood estimation \& inference on cointegration - with applications to the demand for money", Bulletin of Economics and Statistics Oxford Univ. 52, 169-210. Granger, C.W.J.(1969), "Investigating Causal Relations by Econometric Models \& Cross Spectral Methods", Econometrica, 37, str. 424-438.

Engle \& Granger (1987), "Co-integration \& ECM : representation, estimation, and testing", In Econometrica Book, 55, 251-276.

Narayan (2005), "The saving \& investment nexus for China: evidence from cointegration tests", Applied Economics, 37, 1979-1990.

Narayan \& Smyth (2008), "Energy consumption \& real GDP in G7 countries: new evidence from panel cointegration with structural breaks", in journal Energy Economics, 30, 2331- 2341.

Narayan \& Prasad (2008), "Electricity consumption real GDP causality nexus: evidence from a bootstrapped causality test in OECD countries", in journal Energy Policy, 36, 910- 918.

Pesaran, at, al (2001). Bounds Testing Approaches to the Analysis of Level Relationships; In Journal of Applied Econometrics, Vol. 16, pp. 289-326

http://jurnal-sdm.blogspot.co.id/2009/06/produk-domestik-bruto-pdbgross-domestic.html, accessed: October, 13-20, 2016. 